\title{
Hydropower impact on the river flow of a humid regional climate
}

\author{
Julian David Hunt ${ }^{1}$ (D) - Giacomo Falchetta ${ }^{2}$ - Behnam Zakeri ${ }^{1,3}$. \\ Andreas Nascimento ${ }^{4}$. Paulo Smith Schneider ${ }^{5}$. Natália Assis Brasil Weber ${ }^{5}$. \\ André Luiz Amarante Mesquita ${ }^{6}$. Paulo Sergio Franco Barbosa ${ }^{7}$. \\ Nivalde José de Castro ${ }^{8}$
}

Received: 26 February 2020 / Accepted: 10 August 2020 /Published online: 3 September 2020

(C) The Author(s) 2020

\begin{abstract}
Land use and water management have considerable impacts on regional climates. This paper proposes that in humid regions with low wind patterns the construction of hydropower storage reservoirs contributes to the increases in the probability of precipitation in the regional climate. This observation has been tested with a methodology that calculates the cumulative influence of reservoir construction in the basins surrounding with a proposed index named Cumulative Impact of Existing Reservoirs, and compares this index with the historical flow of the rivers. It was found that the construction of reservoirs in Brazil had a considerable impact on its river flows.
\end{abstract}

Keywords Land use $\cdot$ Regional climate $\cdot$ Water management $\cdot$ Drought

Electronic supplementary material The online version of this article (https://doi.org/10.1007/s10584-02002828-w) contains supplementary material, which is available to authorized users.

Julian David Hunt

hunt@iiasa.ac.at

1 International Institute of Applied Systems Analysis (IIASA), Vienna, Austria

2 FEEM-Fondazione Eni Enrico Mattei, Milan, Italy

3 Sustainable Energy Planning Research Group, Aalborg University of Copenhagen, Copenhagen, Denmark

4 Federal University of Espirito Santo, Vitória, Brazil

5 Federal University of Rio Grande do Sul, Porto Alegre, Brazil

6 Federal University of Pará, Belém, Brazil

7 Núcleo Interdisciplinar de Planejamento Energético, University of Campinas, Campinas, Brazil

8 Grupo de Estudos do Setor Elétrico, Federal University of Rio de Janeiro, Rio de Janeiro, Brazil 


\section{Introduction}

Land use can have a substantial impact on the climate and precipitation profile of a region. These impacts can be very diverse. For instance, conversion of forest into agricultural land affects precipitation patterns ( $\mathrm{Li}$ et al. 2009; Adnana and Atkinson 2011; Price 2011), the impact of deforestation can affect regional average temperatures (Bonan 1997) as well as other impacts (DeAngelis et al. 2010; Mueller et al. 2015; Chen and Dirmeyer 2017). Apart from the changes in land use, water consumption patterns, which affect the evapotranspiration of a region, also affect the regional climate (Hunt and Leal Filho 2018; Liu et al. 2018; Zou et al. 2018). A particular area of research that has gained much attention is the impact of agriculture irrigation on regional temperature and precipitation (Kueppers et al. 2007; Thiery et al. 2017; Chen and Jeong 2018; Chen and Dirmeyer 2019). Looking in detail into these studies, it can be concluded that agricultural irrigation increases the humidity of the soil and atmosphere, and for evaporation to occur, water extracts heat from the air, which reduces the regional average temperature. In other words, land and water management have an important impact on regional climate (Betts 2001; Tomer and Schilling 2009). This correlation between land and water management and climate has even been proposed as a regional adaptation measure for global warming (Hirsch et al. 2017), and included into weather forecast models (Li et al. 2018).

There are several research projects on the impact of climate change on hydropower generation (Markoff and Cullen 2008; Madani and Lund 2010; Hamududu and Killingtveit 2012; Gaudard et al. 2013; Viola et al. 2015; Arango-Aramburo et al. 2019). However, only a few papers study the impact of hydropower reservoirs on the climate, see for example Wu et al. (2012), Song et al. (2017), and Balagizi et al. (2018). This might be due to the low surface area of hydropower reservoirs around the world. However, when considering large reservoirs such as the Three Gorges Dam, their impact on the regional climate can be important. Other cases where large reservoirs are common are in Brazil, Russia, and Canada.

Looking at the impact of large reservoirs on the overall basin flow, large hydropower reservoirs result in high levels of evaporation, which reduces the overall yearly river flow downstream (Beilfuss 2010; López-Moreno et al. 2014; Zhang et al. 2015; Digna et al. 2018). In Brazil, the Southeast region presents two well-defined seasons, of which one is a dry season where relative humidity strongly decreases. Usually, relative humidity is at its minimum from August to the beginning of October, and evaporation peaks. Although this period is long, it occurs when reservoir levels and river flows are at their lower levels (Althoff et al. 2020), which reduces evaporation losses.

During the wet season in the Southeast region in Brazil, the average relative humidity of the atmosphere at the surface is very high, and this considerably reduces the reservoir evaporation. On the other hand, by increasing the regional humidity through evaporation, the evaporation contributes to the increase in precipitation in the region. This paper argues that in the Brazilian Southeast river basins the larger the hydropower reservoir surface area is, the higher the precipitation in the region and the larger will be the flow of the river. Many studies argue and can be cited to back up this affirmation using similar assumptions and methodologies (Degu et al. 2011; Duerinck et al. 2016; Lathuilliere et al. 2016). During the dry period, precipitation is substantially reduced and any contribution from the reservoir to a possible increase in precipitation would be considerably smaller than during the wet period.

Historically, the Brazilian energy sector has been affected by multiple energy crises of different durations and geographic ranges such as the crises of the years 1924, 1944, 1955, 1964, 1986, 2001, and 2014 (Hunt et al. 2018a). In most cases, the causes of crises were 
associated with climatic conditions, what directly impacts the hydro dominant power system of the country. After the water and energy crises, a great effort was made by the governments to replenish the levels of the reservoirs of the hydroelectric plants to avoid future crises.

The Brazilian Southeast has been suffering a considerable reduction of river flow on the upper Paraná River basin, since the 2014-2015 drought (Melo et al. 2016; Hunt et al. 2018b). This paper argues that the reduction in river flow is partially caused by the reduction in the storage reservoirs at the head of the river.

This paper is divided into four sections. Section 2 explains the impact of the hydropower reservoir levels on regional precipitation and presents the methodology used to validate the theory, based on the construction of new reservoirs. Section 3 presents the results of the paper. Section 4 discusses the findings of this research. Section 5 concludes the paper.

\section{Methodology}

In Brazil, hydropower reservoirs have very large flooded areas (Dias et al. 2018). For example, considering the 21 dams, with a reservoir surface area larger than $50 \mathrm{~km}^{2}$, inside or on the border of the São Paulo State, these occupy a total area of $8766 \mathrm{~km}^{2}$. This is equivalent to $3.53 \%$ of the area of the whole state, see Table 1. Given the large percentage of reservoir area in Brazil, this paper argues that these reservoirs have a strong impact on the regional climate. For instance, the total reservoir area in Brazil is around 37,022 $\mathrm{km}^{2}$ (ONS 2013), which is similar to the area of Switzerland. Furthermore, the reservoirs increase the soil humidity of the basin, particularly in sedimentary basins with a low slope.

Most storage reservoirs in Brazil were designed without consideration for social and environmental impacts on its surroundings (Nilsson and Dynesius 1994; Passamani and Serpa Cerboncini 2013; Dai et al. 2018); thus, they have a large flooded area variation, as presented in Table 2 (Hunt et al. 2018a). Some very large reservoirs are left with only $30 \%$ of the flooded area during the dry period when the environment and surrounding communities need water the most.

Approximately $70 \%$ of Brazil's hydroelectric energy storage capacity are in the Southeast and Central-West region of Brazil. When there is a drought in this region, the energy storage reservoirs do not fill up and the country must increase thermoelectric generation, raise electricity prices, reduce electricity demand, and even implement electricity rationing policies. The concentration of $70 \%$ of the country's energy storage capacity in a region with similar climatic behavior, including a similar seasonal pattern, results in an enormous vulnerability of the Brazilian electric sector and is one of the main causes of the energy crises in the country.

Table 1 Reservoir area inside or bordering selected states in Brazil (only reservoirs larger than $50 \mathrm{~km}^{2}$ are considered) (ONS 2013)

\begin{tabular}{lllll}
\hline Region & Area $\left(\mathrm{km}^{2}\right)$ & Reservoir area $\left(\mathrm{km}^{2}\right)$ & $\begin{array}{l}\text { Percentage of } \\
\text { reservoir area }(\%)\end{array}$ & Number of reservoirs \\
\hline São Paulo & 248,209 & 8766 & 3.53 & 21 \\
Parana & 199,315 & 3188 & 1.60 & 10 \\
Minas Gerais & 586,528 & 8529 & 1.45 & 20 \\
Goias & 340,086 & 5905 & 1.74 & 6 \\
Mato Grosso do Sul & 903,378 & 6060 & 0.67 & 5 \\
Bahia & 567,295 & 4526 & 0.80 & 82 \\
Brazil total & $8,515,767$ & 37,022 & 0.45 & 8 \\
\hline
\end{tabular}


Table 2 Storage reservoir flooded area variation in Brazil (ONS 2013)

\begin{tabular}{llll}
\hline Dam & $\begin{array}{l}\text { Maximum flooded } \\
\text { area }\left(\mathrm{km}^{2}\right)\end{array}$ & $\begin{array}{l}\text { Minimum flooded } \\
\text { area }\left(\mathrm{km}^{2}\right)\end{array}$ & $\begin{array}{l}\text { Flooded area } \\
\text { variation }(\%)\end{array}$ \\
\hline Billings & 125 & 1 & 99 \\
Furnas & 1442 & 530 & 63 \\
Três Marias & 1064 & 369 & 65 \\
Barra Bonita & 310 & 125 & 60 \\
Jurumirim & 450 & 324 & 28 \\
Passo Real & 225 & 43 & 81 \\
Ilha Solteira & 1196 & 633.72 & 47 \\
Emborcação & 478 & 150 & 69 \\
Itumbiara & 797 & 272.82 & 66 \\
Marimbondo & 438 & 118 & 73 \\
Serra da Mesa & 1783 & 454.28 & 76 \\
Salto Santiago & 208 & 123 & 41 \\
Sobradinho & 4196 & 1143 & 73 \\
Bento Munhoz & 142 & 56 & 61 \\
Tucuruí & 3024 & 761 & 75 \\
\hline
\end{tabular}

The methodology proposed in this paper assumes that the increase in reservoir flooded area in one region increases the precipitation of the region, and reduces the precipitation of the regions surrounding it. To verify this methodology, a model has been developed focusing on the construction of reservoirs. The model consider changes in flooded areas with the construction of reservoirs and the distance of the reservoir from the basin under analysis. It does not take into account other land use changes, such as deforestation, irrigation, and urbanization.

This thesis is particularly difficult to prove because there are two correlations between precipitation and reservoirs. One causal correlation and the consequential correlation. The consequential correlation is the easiest to understand. When it rains more than the average, reservoir fills up. The causal correlation is more difficult to justify, and is the objective of this paper. When the reservoirs are full, more rain happens.

The method proposed to analyze the impact of the construction of new reservoirs on river flow considers the creation of an index named Cumulative Impact of Existing Reservoirs index (CIER), which is an empirical value product of the area of the existing reservoirs in a basin and a coefficient which varies with the distance between the reservoir under analysis and the basin affected by these reservoirs, see Eq. (1) and Table 3. The model only considers dams that have a reservoir larger than $50 \mathrm{~km}^{2}$. This model is then compared with the observed flow of the river where the main reservoirs are located. If the results obtained through this method vary similarly to observed river flows, then the method can be validated. A representation of the basins under analysis and the impact of reservoirs in the Southeast and Southern region basins is shown in Fig. 1.

$$
C I E R_{y}=\sum_{r=1}^{R} \sum_{d=1}^{D} A_{r} \times c_{d}
$$

Where:

$C I E R_{y}$ is the Cumulative Impact of Existing Reservoirs index for year $y$ on the flow of the river under analysis.

$r \quad$ is the index of the reservoirs with flooded areas larger than $50 \mathrm{~km}^{2}$. 
Table 3 Reservoir impact coefficient variation with distance and region

\begin{tabular}{lll}
\hline Distance $(\mathrm{km})$ & \multicolumn{1}{c}{$c_{d}$} & South \\
\cline { 2 - 3 } & Southeast & 1 \\
\hline distance $<100$ & 1 & 1 \\
$>100$ distance $\leq 200$ & 1 & 1 \\
$>200$ distance $\leq 300$ & 1 & -0.05 \\
$>300$ distance $\leq 400$ & 1 & -0.01 \\
$>400$ distance $\leq 500$ & 1 & -0.01 \\
$>500$ distance $\leq 600$ & 0.5 & -0.05 \\
$>600$ distance $\leq 700$ & -1 & 0 \\
$>700$ distance $\leq 800$ & -0.25 & 0 \\
$>800$ distance $\leq 900$ & -0.25 & 0 \\
$>900$ distance $\leq 1000$ & -0.25 & 0 \\
distance $>1000$ & 0 & \\
\hline
\end{tabular}
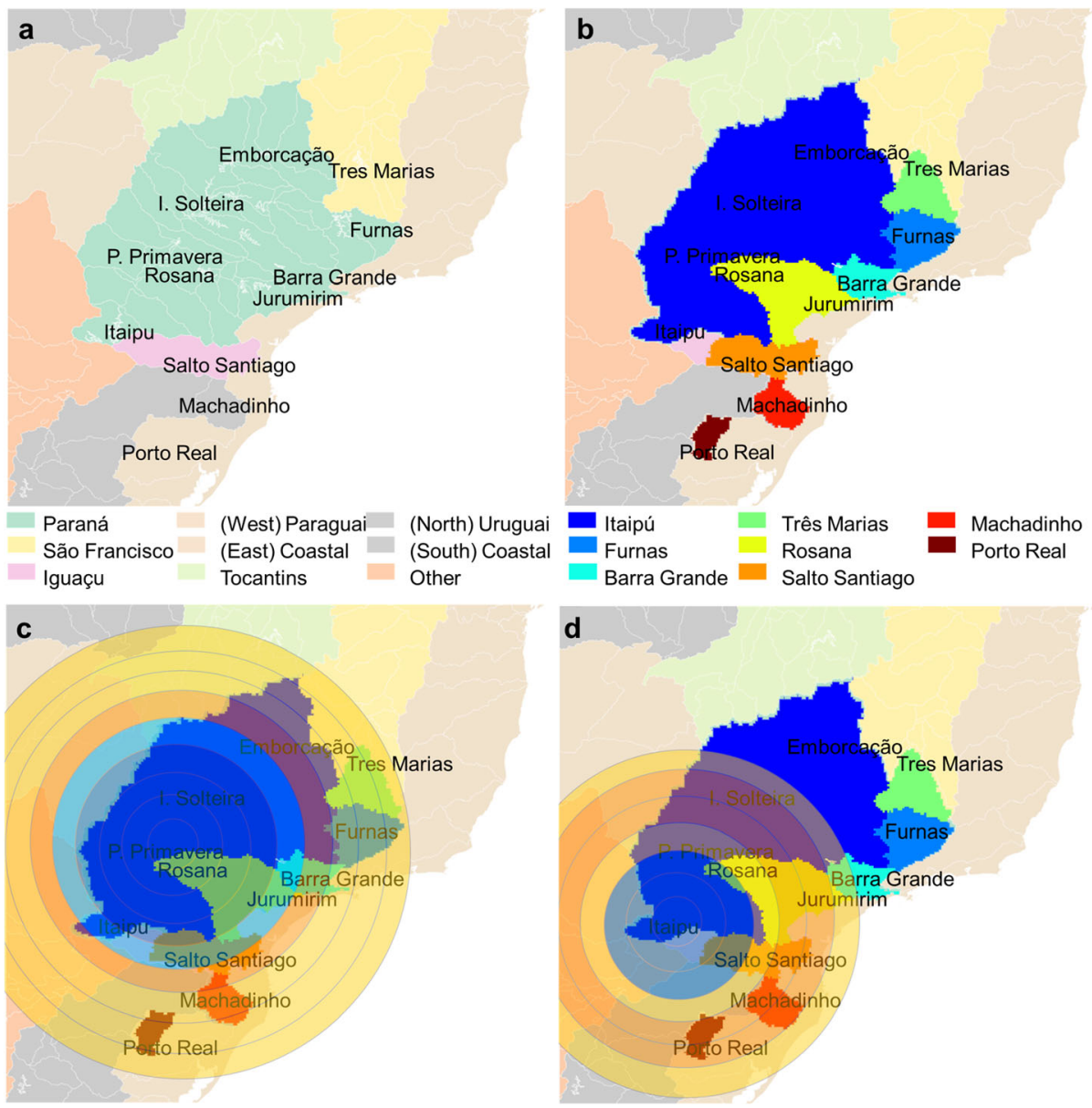

Fig. 1 Details of the (a) major basin and reservoirs in Brazil, (b) basin under analysis in this study, (c) the impact of the Porto Primavera reservoir on the Southeast region basins, and (d) the impact of Itaipú reservoir on the Southern region basins 
$d \quad$ is the index of the distance $(\mathrm{km})$ between the existing reservoirs at year $y$ and the river basin under analysis. In the model, the reservoir has a fixed coordinate and the basin has multiple coordinates, one per grid cell.

$A_{r}$ is the reservoir area $\left(\mathrm{km}^{2}\right)$.

$c_{d}$ is the coefficient of reservoir impact (\%) at distance $d \mathrm{~km}$ for the basin under analysis.

The coefficient of reservoir impact, as described in Eq. (1) suggests that reservoirs close to the basin under analysis will contribute to increase the flow of the river, while reservoirs far from the river will contribute to reducing the flow of the river. This is because a warm and humid weather front from the Amazon or a cold front from the South reaching the Southeast region brings a limited potential for rain harnessing. If the chance for rain in one location increases, this reduces the chance of rain in locations on the surroundings. For example, if the rain event happens close to the Itaipú reservoir, it will reduce the potential for rain to happen in the regions surrounding the Itaipú reservoir. If the reservoir is very far from the river basin, its impact is neglected. The correlation between the distance of the reservoir to the basin and impact on the river flow was found to have different profiles for river basins in the Southeast and South regions of Brazil. The correlation applied to the results in this paper is presented in Table 3. The coefficient of reservoir impact and the impact radius have been proposed by the authors and adjusted with a trial and error approach to fit the CIER index as much as possible with the observer flowrate of the basins in the Southeast and South regions.

The data used to reproduce the basins' boundaries were taken from HydroBASINS (Lehner and Grill 2013). This data has been transformed into gridded data with a resolution of $0.25^{\circ}$. The details of the reservoirs considered in this study, such as coordinates, construction date, and flooded areas were taken from the Brazilian National Grid (ONS 2013).

After the CIER index is calculated with Eq. (1), the value is adjusted to facilitate the comparison with the 9-year running average dam natural inflow. These adjustments are made with the addition of a constant " $b$ " and multiplication of another constant "a" to the CIER index. The final selected $a$ and $b$ constants are a result of the smallest Euclidean distance as described in Eq. (2).

$$
E D=\sum_{y=0}^{Y} \sqrt{\left(C I E R_{y} \times a+b\right)^{2}-F_{y}^{2}}
$$

Where:

$E D$ is the Euclidian distance between the adjusted CIER index curve and the 9-year running average dam natural inflow.

$a$ and $b$ are constants to adjust the CIER index. $a$ varies from 100 to 0.01 , and $b$ varies between plus and minus the maximum value of the dam natural inflow.

$F_{y}$ is the 9-year running average dam natural inflow in $\left(\mathrm{m}^{3} / \mathrm{s}\right)$ on year $y$.

$Y$ is the total number of years with data available.

\section{Results}

The Cumulative Impact of Existing Reservoirs index has been compared with the historical natural river flows for the Itaipú, Furnas, Barra Bonita, Três Marias (Fig. 2), Rosana, Salto Santiago, Machadinho, and Passo Real Dams (Fig. 3). The natural river flow assumes that 
there are no dams on the river and that the precipitation in the basin would flow to the location under analysis with no human intervention. The CIER index is calculated for each year, assuming the with Eq. (1) and is adjusted to fit in the same axis as the yearly dam flow to facilitate the comparison. The variation of the CIER index in Fig. 2 is compared with the historical river flows to validate the methodology described in this paper and as a form to justify the changes in the natural river flow of the dams under analysis and show that the proposed methodology in the paper has valid fundaments.

Figure 2 (a) shows that the 9-years running average dam natural inflow at the Itaipú dam location started to increase from 1950 (when a lot of dams were built in the basin) until it reaches a relatively constant value, similarly to the adjusted CIER index. The similarity between the 9-years running average dam natural and the adjusted CIER index indicates that the thesis proposed in this paper is valid. Thus, the reason for the observed increase in flow in the Itaipú Dam from 1930 to 2018 is a result of the construction of dams in the Paraná Basin, which resulted in an increase in precipitation in the basin. As the Itaipú dam is the most downstream dam in the Paraná Basin, thus, it receives a positive contribution from all reservoirs in the Paraná Basin.

Figure 2 (b) presents the analysis for the Furnas Dam, where the historical flow constantly fluctuated. The adjusted CIER index for Furnas also fluctuates with the construction of the reservoirs in the southeast region, however, this fluctuation does not match the historical flow. The variation in flow in the Furnas Dam is better explained by the level of the reservoirs of existing reservoirs, as explained in Section 4.2. It can be seen, however, that the CIER index indicates that there is no overall tread for increasing of reducing the flow of the dam, which is what happens with the 9-years running average dam natural inflow. The historical flow 9 years running average increases with the construction of Mascarenhas, Furnas, Marimbondo, and Água Vermelha and reduces with Ilha Solteira, Itaipú, and Porto Primavera.

Figure 2 (c) presents the analysis for Barra Bonita Dam, where its historical flow 9-years running average matches almost perfectly with the adjusted CIER index. That is, increasing
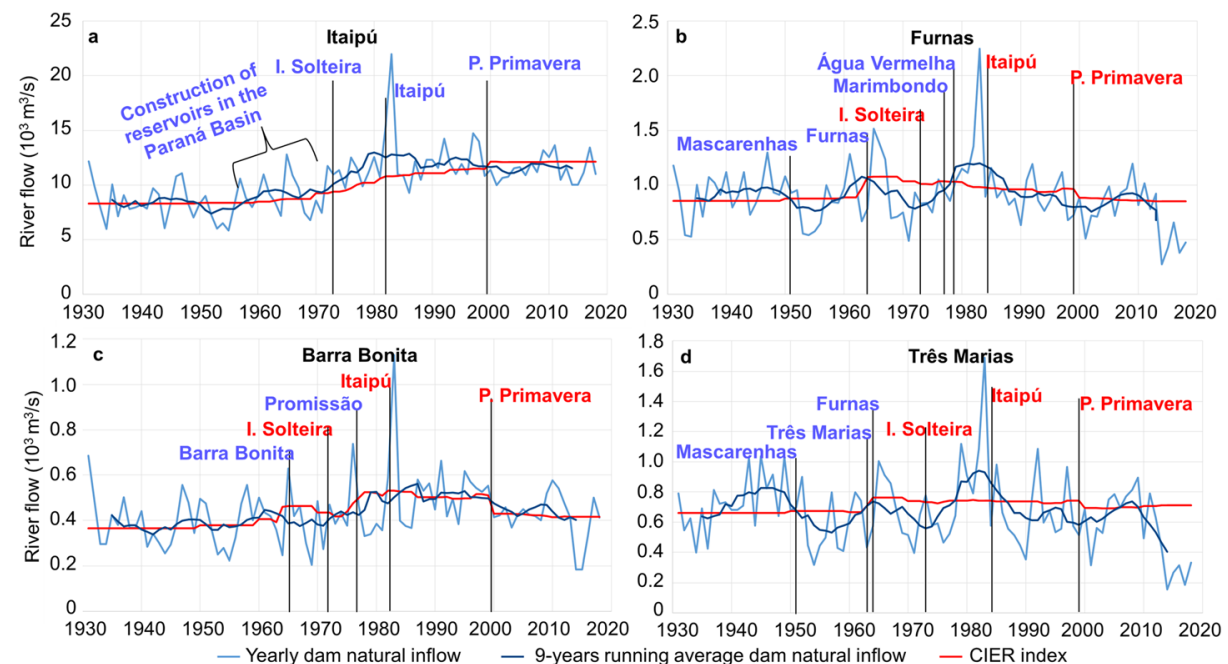

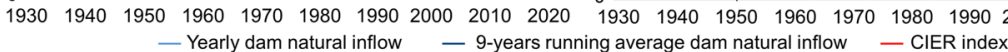

Fig. 2 Comparison between river inflow and Cumulative Impact of Existing Reservoirs index for reservoirs (a) Itaipú, (b) Furnas, (c) Barra Bonita, and (d) Três Marias in the Southeast region. The reservoir names in red impact negatively on the inflow of the reservoir under analysis. The reservoirs in blue impact positively 


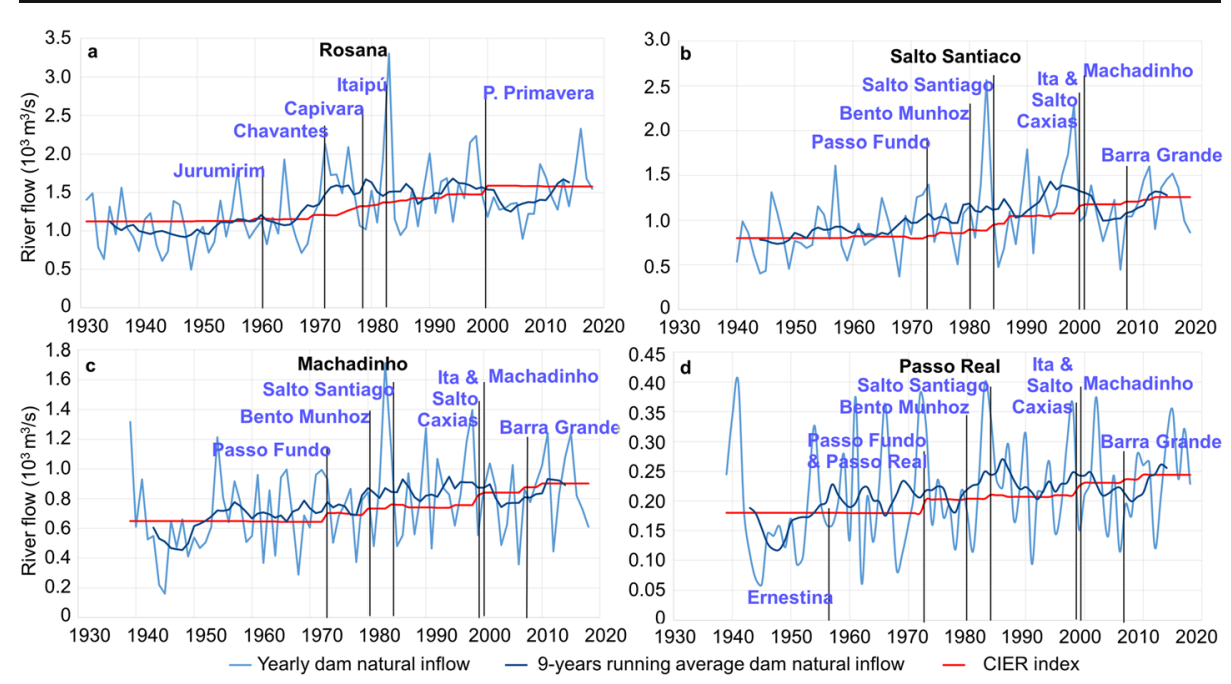

Fig. 3 Comparison between river inflow and CIER index for reservoirs (a) Rosana Southeast region, (b) Salto Santiago, (c) Machadinho, and (d) Passo Real in the Southern region

with the construction of Barra Bonita and Promissão Dam and reducing with the construction of Ilha Solteira, Itaipú, and Porto Primavera. Barra Bonita is a good indication that the proposed methodology is valid. The change is storage are might not have a substantial impact on the discharge when compared with the Furnas Dam, because the maximum flooded area of Barra Bonita is only $310 \mathrm{~km}^{2}$, while Furnas is $1.442 \mathrm{~km}^{2}$ (Table 2). Thus, the impact of dam construction in Barra Bonita might be higher than the impact of the reservoir level variation.

Figure 2 (d) presents the analysis for Três Marias Dam and behaves similarly to Furnas, and that its flow increases with the construction of Três Marias and Furnas and reduces with the construction of Ilha Solteira, Itaipú, and Porto Primavera. Its intense fluctuation is also best explained with the reservoir level variation (Section 4.2), as Três Marias has a large flooded area $\left(1064 \mathrm{~km}^{2}\right)$ and a flooded area maximum variation of $64 \%$.

Generally, the construction of the plants in Paraná River, Ilha Solteira, Itaipú, and Porto Primavera increased the precipitation in Itaipú Dam and reduced the flow in Furnas, Barra Bonita, and Três Marias Dams. It is important to notice that the river flow from Furnas, Barra Bonita, and Três Marias considerably drops after 2014. This is due to the 2014 drought in the Southeast region, which considerably impacted the reservoir levels. This impact is not related to the construction of new reservoirs, but with the storage levels of the, existing reservoirs, which were very low. This is discussed in Section 4.2.

In the south, the Rosana Dam historical inflow 9-years moving average starts to increase in 1965 and remains relatively constant until 2018 as shown in Fig. 3 (a). This variation follows the tendency seen in the adjusted CIER index of the dam and increases with the construction of the Jurumirim, Chavantes, Capivara and Itaipú, and Porto Primavera Dams. This is because of the proximity of the Rosana Reservoir to large run-off the river reservoir such as Porto Primavera and Itaipú.

The Salto Santiago Dam historical 9-year average inflow varies accordingly with the adjusted CIER index of the dam and its flow increases with the construction of Passo Fundo, Bento Munhoz, Salto Santiago, Ita, Salto Caxias, Machado, and Barra Grande as shown in Fig. 3 (b). Figure 3 (c) shows that Machadinho Dam historical 9-year average inflow varies 
similarly to the adjusted CIER index and increases with the construction of Passo Fundo, Bento Munhoz, Salto Santiago, Itá, Salto Caxias, Machadinho, and Barra Grande Dams. Figure 3 (d) shows that the Passo Real Dam historical 9-year average inflow varies similarly to the adjusted CIER index, and increases with the construction of Ernestina, Passo Fundo, Passo Real, Bento Munhoz, Salto Santiago, Itá, Salto Caxias, and Machadinho Dams. All dams analyzed in the South of Brazil have increased their yearly discharge from 1930 to 2018. This increase in discharge could be a consequence of the impact the construction of dams in the region had in the regional climate, increasing precipitation, as proposed in this paper.

\section{Discussion}

\subsection{Impact of reservoirs on regional humid climates}

A possible explanation for the impact of reservoirs in humid climates is that, during the wet period, the Southeast region of Brazil (between November and April), the average humidity is around 70\% with low average wind speeds (INPE 2019). Thus, the evaporation is low and the additional evaporation, contributes to increasing regional precipitation, which ultimately increases the river flow of the reservoir. When the storage reservoirs are full, the flooded area and the soil humidity surrounding the reservoir increases. This increases evaporation rates, which increases the humidity of the air and reduces the temperature of the regional climate. With a more humid and colder atmosphere, when a warm and humid weather system reaches these reservoirs, the chance of precipitation increases. On the other hand, when storage reservoirs are empty, the flooded area and soil humidity surrounding the reservoir are lower. This reduces evaporation rates, which reduces the humidity of the air and increases the temperature of the regional climate. With a less humid and warmer atmosphere, when a warm and humid front reaches these reservoirs, the chances of precipitation reduces. A visual representation of this phenomenon is shown in Fig. 4.

The impact of the construction of dams might only increase the river flowrate of the basins in humid regional climates with low speed with patterns. This is because the high humidity reduces the evapotranspiration potential and the low wind speed patterns maintain the humidity levels surrounding the reservoir high. Other regions, for example, the Keban Dam in Turkey, the impact of the reservoir in precipitation patterns was negligible (Downing et al. 2006).

\subsection{Impact of reservoir operation on a regional humid climate}

Apart from the impact of the construction of reservoirs, the operation of the reservoirs might also impact the regional climate. This relation could be analyzed comparing the precipitation in the region of Itaipú (Fig. 5 (a)) and Emborcação (Fig. 5 (b)), with the reservoir levels in the Southeast region, which is a good indicator of the reservoir flooded area of the region. This is because, the largest seasonal and multi-annual storage reservoirs in Brazil are located surrounding the Emborcação reservoirs, thus, the flooded area surrounding Emborcação will vary considerably with the storage capacity of the country. On the other hand, the surroundings of Itaipú are where most of the run-of-the river dams are located. In other words, regardless the change in energy storage of the country, the flooded area of the reservoirs surrounding Itaipú does not vary substantially. This is represented in Fig. 6 (a) and (b). 
a

Higher chances of precipitation

Full reservoirs

Higher humidity, lower temperature, denser air Higher evaporation

Higher soil humidity Higher flooded area

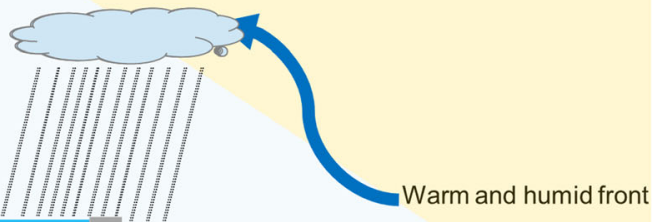

b Lower chances of precipitation Empty reservoirs

U

Lower humidity and higher temperature, lighter air

已

Lower evaporation
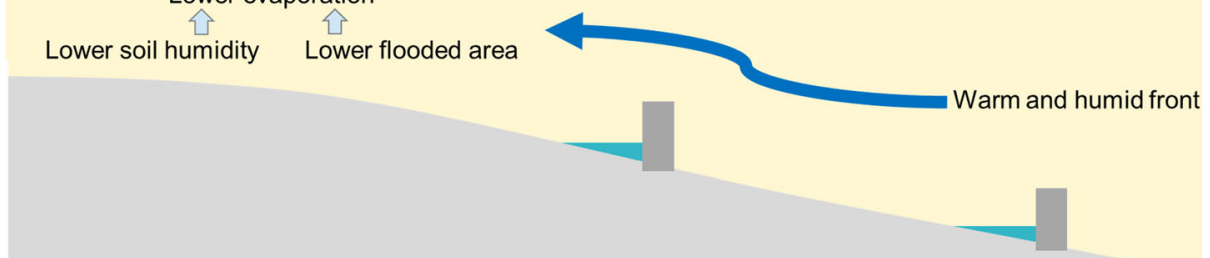

Fig. 4 Diagram explaining the impact of the hydropower reservoir levels on regional precipitation. Note that the wind blows from different directions

Figure 6 presents an axial representation of the existing hydropower dams in the Paranaíba river (from the Batalha Reservoir to Ilha Solteira Reservoir) and Paraná River (from Ilha Solteira Reservoir to Itaipú Reservoir). Most of the dams in the Paranaíba River have substantial storage capacity. This large storage capacity results in a total flooded area of $5512 \mathrm{~km}^{2}$, when reservoirs are full, and flooded area of $3298 \mathrm{~km}^{2}$, when reservoirs are empty. This consists of a total flooded area variation of $40 \%$. The dams in the Paraná River, where the
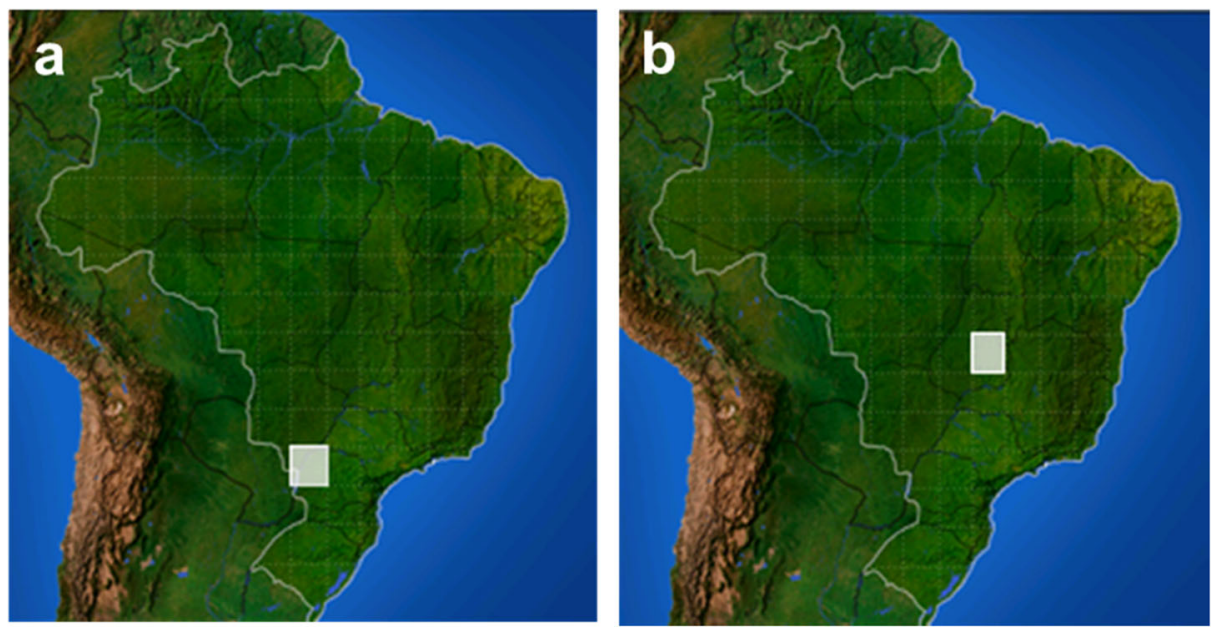

Fig. 5 The region of (a) Itaipú and (b) Emborcação (INPE and CPTEC 2019) 


\section{Full Storage Reservoirs}

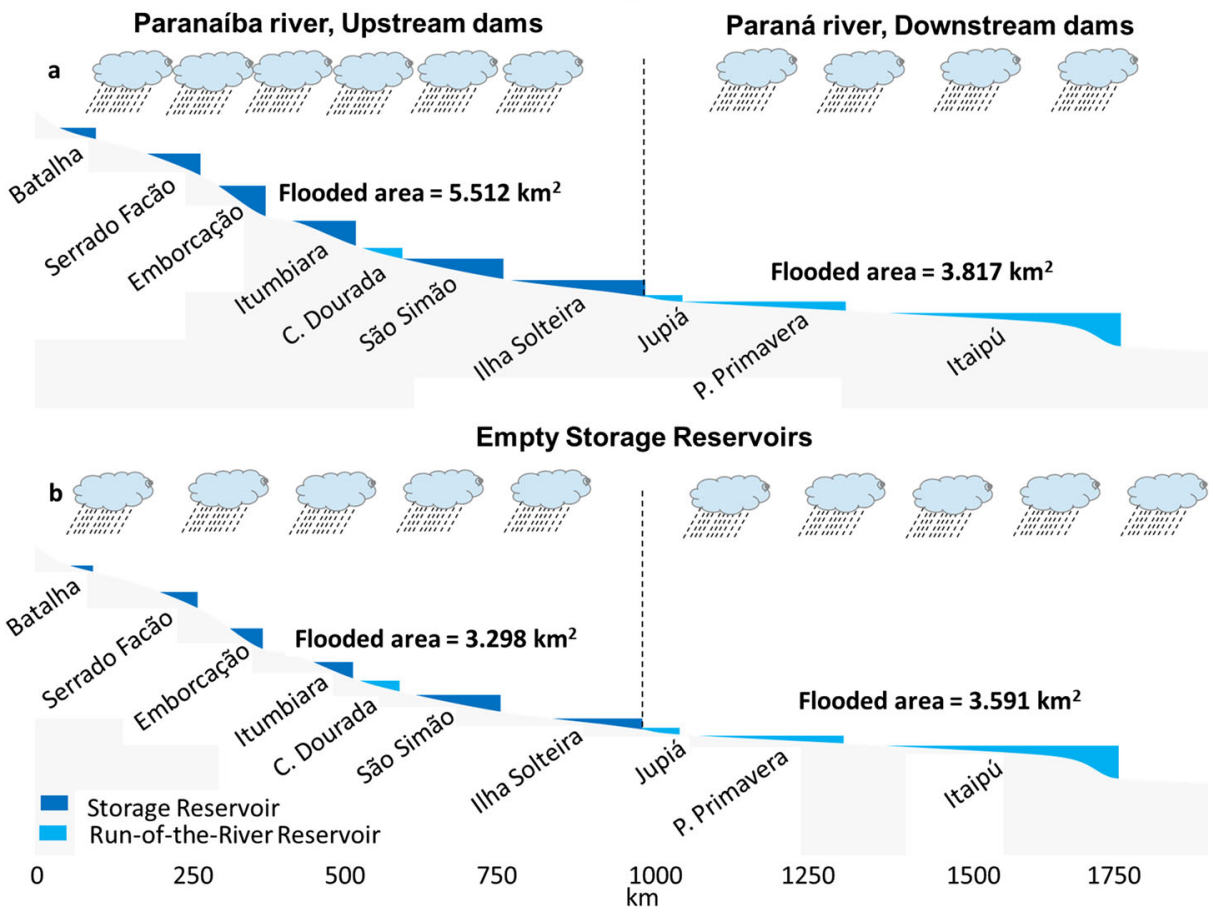

Fig. 6 Impact of reservoir operation on the regional climate. (a) Full storage reservoirs, more rain on the head of the river and (b) Empty storage reservoirs, less rain on the head of the river

Itaipú Dam is located, are run-of-the-river and have limited storage capacity and their flooded area varies from $3817 \mathrm{~km}^{2}$, when full, and $3591 \mathrm{~km}^{2}$, when empty, which consists of a total flooded area variation of $6 \%$. Thus, when the storage levels of the Southeast region are low, the flooded area of the dams upstream are much more impacted than the flooded area of the dams downstream. Considering the methodology proposed in Fig. 4, during the wet period, there would be more precipitation on the upstream dams if the storage reservoirs are full and more precipitation on the downstream dams when the storage reservoirs are empty.

This analysis is intended to show that, when the Southeast reservoirs are full, there is more precipitation at the head of the river, where the storage reservoirs are located and where the combined hydropower generation head of the dams in cascade is as high as $600 \mathrm{~m}$. When the reservoirs are empty, there is more precipitation downstream of the river, where the run-of-theriver dams are located, and the hydropower generation head is limited to the Itaipú Dam with only $112 \mathrm{~m}$.

The impact of reservoir operation on basin river flows is presented in Fig. 7. The 9-year average precipitation surrounding the Emborcação Dam follows the Southeast energy storage percentage. This is expected because the inflow is directly proportional to the water and energy storage of the reservoirs, given that the inflow fills up the reservoir. What should be observed in detail is that when the reservoirs are lower, the chances of precipitation happening in Itaipú increases. In other words, when the Southeastern reservoirs are low, the rain that would normally happen in the region is diverged into Itaipú, where the flooded area does not vary because the reservoirs surrounding it are mostly run-of-the-river. 


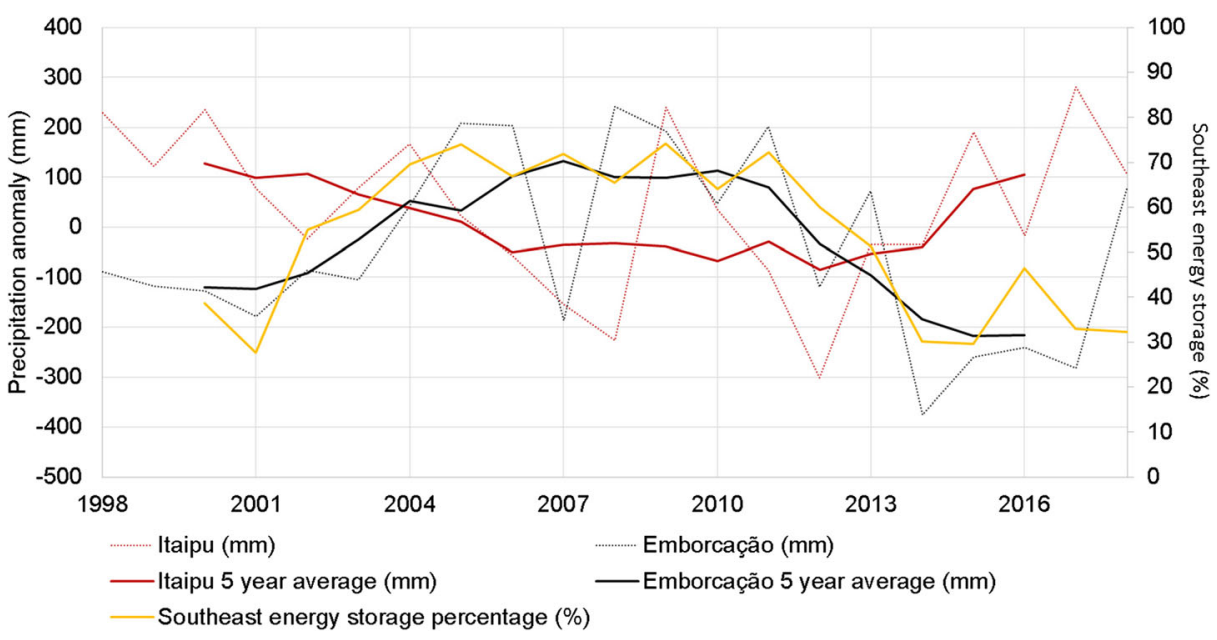

Fig. 7 Comparison between precipitation at Itaipú and Emborcação, and the Southeast storage capacity (INPE and CPTEC 2019; ONS 2019)

\subsection{Use of reservoirs to reduce climate vulnerability}

Climate change will increase the frequency and intensify floods and droughts (Ehsani et al. 2017). Having a clear indication that a particular year will result in severe floods in humid regions, more hydropower can be generated, reducing reservoir levels, as an approach to reduce the chances of precipitation and, thus, the impacts of floods. On the other hand, if there is a clear indication of a drought in the following months, hydropower can be curtailed for the dam level to increase, to increase the chances of precipitation. This alternative to manage the climate can be a strong alternative to mitigate vulnerabilities in the water and energy sectors of humid climates.

Brazil's economy strongly relies on agriculture, which in turn relies on rainfall patterns and river flow. Many studies discuss the increase in small reservoir numbers for reduced water vulnerability (Andreini et al. 2003; Krol et al. 2011; Malveira et al. 2012; Dong et al. 2019; Althoff et al. 2020). The Southeast region has gone through eight severe droughts since 1920 (Hunt et al. 2018b). In 2001, a great effort was made to allow the reservoirs to return to their original levels. This resulted in a short-term water and energy crisis. However, in the 2014 crisis, there was no operational policy in place for the reservoir levels to return to their previous levels so the average annual precipitation on storage reservoirs has not yet returned to previous levels. To increase precipitation and hydropower generation in Brazil, the government should focus on operating thermal power plants to allow the storage reservoirs to be replenished. The storage reservoirs should be kept at a level of at least $60 \%$ at the end of the dry period to increase the river flow during the wet period, as suggested by the theory proposed in this paper.

One possible issue form this operational change is that the storage capacity available in the river would reduce as the reservoirs are kept partially full. This could increase the amount of water spilled in the dams without generating electricity. This spillage would further increase, particularly, if the impact of the full reservoirs increases the regional precipitation and the river flow. A possible solution to this is to build new reservoirs to increase the storage capacity of the river, looking particularly at seasonal pumped-storage plants, which require a small flooded 
area and have reduced social-economic and environmental impacts (Hunt et al. 2014, 2017, 2018a, 2019), or store energy seasonally within energy crops (Hunt et al. 2016).

Other options to increase the hydropower generation in Brazil include reducing the flooded area in the Paraná River. This could be done by operating the dams at minimum water level or replace the Porto Primavera Dams by two or three smaller dams to reduce its flooded area. This would more than half the flooded area and, thus, reduce the rain that falls directly in the Paraná river basin, with low hydropower potential, but increase the rain on Paranaíba, Grande, and Três Marias Rivers, where most hydropower potential is located.

\section{Conclusion}

This paper has shown that large reservoirs have a considerable impact on the regional climate and these impacts should be considered when planning for the construction of reservoirs in the future, as the reservoirs will impact not only the availability of water in the river basin but also the regional climate, and the climate of the regions surrounding it. In order to increase the hydropower generation in Brazil, which has been at a below-average level for around 5 years, one possible solution is to allow for the increase in the reservoir levels of its dams, which in turn might increase the probability of rain on the head of the basins of the southeast region of Brazil.

Funding Open access funding provided by International Institute for Applied Systems Analysis (IIASA). We would like to thank the CAPES Brazil and IIASA for the research grant and postdoctoral research fellowship and the R\&D funding from the Brazilian Agency of Electric Energy, Enercan, BAESA, Ceran, Foz do Chapecó, Paulista Lajeado Energia and CPFL.

Open Access This article is licensed under a Creative Commons Attribution 4.0 International License, which permits use, sharing, adaptation, distribution and reproduction in any medium or format, as long as you give appropriate credit to the original author(s) and the source, provide a link to the Creative Commons licence, and indicate if changes were made. The images or other third party material in this article are included in the article's Creative Commons licence, unless indicated otherwise in a credit line to the material. If material is not included in the article's Creative Commons licence and your intended use is not permitted by statutory regulation or exceeds the permitted use, you will need to obtain permission directly from the copyright holder. To view a copy of this licence, visit http://creativecommons.org/licenses/by/4.0/.

\section{References}

Adnana N, Atkinson P (2011) Exploring the impact of climate and land use changes on streamflow trends in a monsoon catchment. Int J Climatol 31:815-831

Althoff D, Rodrigues L, Silva D (2020) Impacts of climate change on the evaporation and availability of water in small reservoirs in the Brazilian savannah. Clim Chang 159:215-232. https://doi.org/10.1007/s10584-02002656-y

Andreini M, Andah W, Boelee E (2003) Planning and evaluating ensembles of small, multi-purpose reservoirs for the improvement of smallholder livelihoods and food security: tools and procedures. Colombo, Sri Lanka

Arango-Aramburo S, Turner SWD, Daenzer K et al (2019) Climate impacts on hydropower in Colombia: a multi-model assessment of power sector adaptation pathways. Energy Policy:179-188. https://doi. org/10.1016/j.enpol.2018.12.057

Balagizi CM, Kasereka MM, Cuoco E, Liotta M (2018) Influence of moisture source dynamics and weather patterns on stable isotopes ratios of precipitation in Central-Eastern Africa. Sci Total Environ 628-629: 1058-1078. https://doi.org/10.1016/j.scitotenv.2018.01.284 
Beilfuss R (2010) Modelling trade-offs between hydropower generation and environmental flow scenarios: a case study of the lower Zambezi River Basin, Mozambique. Int J River Basin Manag 8:331-347. https:/doi. org/10.1080/15715124.2010.533643

Betts RA (2001) Biogeophysical impacts of land use on present-day climate: near-surface temperature change and radiative forcing. Atmos Sci Lett 2:39-51. https://doi.org/10.1006/asle.2001.0037

Bonan GB (1997) Effects of land use on the climate of the United States. Clim Chang 37:449-486. https://doi. org/10.1023/A:1005305708775

Chen L, Dirmeyer PA (2019) Global observed and modelled impacts of irrigation on surface temperature. Int J Climatol 39:2587-2600. https://doi.org/10.1002/joc.5973

Chen L, Dirmeyer PA (2017) Impacts of land-use/land-cover change on afternoon precipitation over North America. J Clim 30:2121-2140. https://doi.org/10.1175/JCLI-D-16-0589.1

Chen X, Jeong S-J (2018) Irrigation enhances local warming with greater nocturnal warming effects than daytime cooling effects. Environ Res Lett 13. https:/doi.org/10.1088/1748-9326/aa9dea

Dai N, Lu P, Zhang M et al (2018) Small mammal communities on beaches and lakeside farmland in the Poyang Lake region after the Three-Gorges Project. Mammalia 82:438-448. https://doi.org/10.1515/mammalia2017-0073

DeAngelis A, Dominguez F, Fan Y, et al (2010) Evidence of enhanced precipitation due to irrigation over the Great Plains of the United States J Geophys Res Atmos 115. https://doi.org/10.1029/2010JD013892

Degu AM, Hossain F, Niyogi D et al (2011) The influence of large dams on surrounding climate and precipitation patterns. Geophys Res Lett 38. https://doi.org/10.1029/2010GL046482

Dias VS, da Luz MP, Medero GM, Nascimento DTF (2018) An overview of hydropower reservoirs in Brazil: current situation, future perspectives and impacts of climate change. Water (Switzerland) 10. https://oi. org/10.3390/w10050592

Digna RF, Mohamed YA, van der Zaag P et al (2018) Impact of water resources development on water availability for hydropower production and irrigated agriculture of the Eastern Nile basin. J Water Resour Plan Manag:144. https://doi.org/10.1061/(ASCE)WR.1943-5452.0000912

Dong N, Yu Z, Gu H et al (2019) Climate-induced hydrological impact mitigated by a high-density reservoir network in the Poyang Lake Basin. J Hydrol:124148. https://doi.org/10.1016/j.jhydrol.2019.124148

Downing J, Prairie Y, Cole J et al (2006) The global abundance and size distribution of lakes, ponds, and impoundments. Limnol Oceanogr 51:2388-2397. https://doi.org/10.4319/lo.2006.51.5.2388

Duerinck HM, Ent R, van de Giesen N et al (2016) Observed soil moisture-precipitation feedback in Illinois: a systematic analysis over different scales. J Hydrometeorol 17:160217104557005. https://doi.org/10.1175 /JHM-D-15-0032.1

Ehsani N, Vörösmarty C, Fekete B, Stakhiv E (2017) Reservoir operations under climate change: storage capacity options to mitigate risk. J Hydrol 555. https://doi.org/10.1016/j.jhydrol.2017.09.008

Gaudard L, Gilli M, Romerio F (2013) Climate change impacts on hydropower management. Water Resour Manag 27:5143-5156

Hamududu B, Killingtveit A (2012) Assessing climate change impacts on global hydropower. Energies 5:305322. https://doi.org/10.3390/en5020305

Hirsch AL, Wilhelm M, Davin EL et al (2017) Can climate-effective land management reduce regional warming? J Geophys Res Atmos 122:2269-2288. https://doi.org/10.1002/2016JD026125

Hunt JD, Stilpen D, de Freitas MAV (2018a) A review of the causes, impacts and solutions for electricity supply crises in Brazil. Renew Sust Energ Rev 88. https://doi.org/10.1016/j.rser.2018.02.030

Hunt J, Byers E, Riahi K, Langan S (2018b) Comparison between seasonal pumped-storage and conventional reservoir dams from the water, energy and land nexus perspective. Energy Convers Manag 166:385-401

Hunt J, Byers E, Wada Y et al (2019) Global potential and feasibility of seasonal pumped-storage for energy and water storage. Nat Energy in press

Hunt JD, Freitas MAV, Junior AOP (2014) Enhanced-pumped-storage: combining pumped-storage in a yearly storage cycle with dams in cascade in Brazil. Energy. https://doi.org/10.1016/j.energy.2014.10.038

Hunt JD, Freitas MAVD, Pereira Junior AO (2017) A review of seasonal pumped-storage combined with dams in cascade in Brazil. Renew Sust Energ Rev:70. https://doi.org/10.1016/j.rser.2016.11.255

Hunt JD, Guillot V, de Freitas MAV, Solari RSE (2016) Energy crop storage: an alternative to resolve the problem of unpredictable hydropower generation in Brazil. Energy. https://doi.org/10.1016/j. energy.2016.02.011

Hunt JD, Leal Filho W (2018) Land, water, and wind watershed cycle: a strategic use of water, land and wind for climate change adaptation. Clim Chang 147:427-439. https://doi.org/10.1007/s10584-018-2164-8

INPE (2019) Meteorological graphics. In: http://www.inmet.gov.br/portal/index.php?r=tempo/graficos

INPE, CPTEC (2019) Cumulative precipitation. In: http://clima1.cptec.inpe.br/estacaochuvosa/pt 
Krol M, Vries M, van Oel P, Araújo J (2011) Sustainability of small reservoirs and large scale water availability under current conditions and climate change. Water Resour Manag 25:3017-3026. https://doi.org/10.1007 /s11269-011-9787-0

Kueppers L, Snyder M, Sloan L (2007) Irrigation cooling effect: regional climate forcing by land-use change. Geophys Res Lett 34

Lathuilliere M, Coe M, Johnson M (2016) What could irrigated agriculture mean for Amazonia? A review of green and blue water resources and their trade-offs for future agricultural production in the Amazon Basin. Hydrol Earth Syst Sci Discuss 1-27. https://doi.org/10.5194/hess-2016-71

Lehner B, Grill G (2013) Global river hydrography and network routing: baseline data and new approaches to study the world's large river systems. Hydrol Process 27:2171-2186

Li X, Mitra C, Dong L, Yang Q (2018) Understanding land use change impacts on microclimate using Weather Research and Forecasting (WRF) model. Phys Chem Earth 103:115-126. https://doi.org/10.1016/j. pce.2017.01.017

Li Z, Liu W, Zhang X, Zheng F (2009) Impacts of land use change and climate variability on hydrology in an agricultural catchment on the Loess Plateau of China. J Hydrol 377:35-42

Liu T, Yu L, Bu K, et al (2018) Seasonal local temperature responses to paddy field expansion from rain-fed farmland in the cold and humid Sanjiang Plain of China Remote Sens 10:. https://oi.org/10.3390/rs10122009

López-Moreno JI, Zabalza J, Vicente-Serrano SM et al (2014) Impact of climate and land use change on water availability and reservoir management: scenarios in the Upper Aragón River, Spanish Pyrenees. Sci Total Environ 493:1222-1231. https://doi.org/10.1016/j.scitotenv.2013.09.031

Madani K, Lund JR (2010) Estimated impacts of climate warming on California's high-elevation hydropower. Clim Chang 102:521-538. https://doi.org/10.1007/s10584-009-9750-8

Malveira V, de Araújo J, Güntner A (2012) Hydrological impact of a high-density reservoir network in semiarid northeastern Brazil. J Hydrol Eng 17:109-117. https://doi.org/10.1061/(ASCE)HE.1943-5584.0000404

Markoff MS, Cullen AC (2008) Impact of climate change on Pacific northwest hydropower. Clim Chang 87: 451-469. https://doi.org/10.1007/s10584-007-9306-8

Melo D, Scanlon B, Zhang Z et al (2016) Reservoir storage and hydrologic responses to droughts in the Paraná River basin, south-eastern Brazil. Hydrol Earth Syst Sci 20:4673-4688

Mueller ND, Butler EE, McKinnon KA et al (2015) Cooling of US Midwest summer temperature extremes from cropland intensification. Nat Clim Chang 6:317

Nilsson C, Dynesius M (1994) Ecological effects of river regulation on mammals and birds: a review. Regul Rivers 9

ONS (2013) Dams database for 600 dams in operation, under construction and planning stages - available up on request to ONS and as supplementary information in this paper. Rio de Janeiro

ONS (2019) National Grid Historical Operation. Accessed: 21 Dec. 2019. http://www.ons.org. br/paginas/resultados-da-operacao/historico-da-operacao

Passamani M, Serpa Cerboncini RA (2013) The effects of the creation of a hydroelectric dam on small mammals' communities in centrals Brazil [Efeitos da criação de um reservatório de usina hidrelétrica em comunidades de pequenos mamíferos no Brasil central]. Neotrop Biol Conserv 8:9-16. https://doi.org/10.4013/nbc.2013.81.02

Price K (2011) Effects of watershed topography, soils, land use, and climate on baseflow hydrology in humid regions: a review. Prog Phys Geogr Earth Environ 35:465-492. https://doi.org/10.1177/0309133311402714

Song Z, Liang S, Feng L et al (2017) Temperature changes in three gorges reservoir area and linkage with three gorges project. J Geophys Res 122:4866-4879. https://doi.org/10.1002/2016JD025978

Thiery W, Davin EL, Lawrence DM et al (2017) Present-day irrigation mitigates heat extremes. J Geophys Res Atmos 122:1403-1422. https://doi.org/10.1002/2016JD025740

Tomer MD, Schilling KE (2009) A simple approach to distinguish land-use and climate-change effects on watershed hydrology. J Hydrol 376:24-33. https://doi.org/10.1016/j.jhydrol.2009.07.029

Viola MR, de Mello CR, Chou SC et al (2015) Assessing climate change impacts on Upper Grande River basin hydrology, Southeast Brazil. Int J Climatol 35:1054-1068. https://doi.org/10.1002/joc.4038

Wu J, Gao X, Giorgi F et al (2012) Climate effects of the Three Gorges Reservoir as simulated by a high resolution double nested regional climate model. Quat Int 282:27-36. https://doi.org/10.1016/j.quaint.2012.04.028

Zhang Y, Block P, Hammond M, King A (2015) Ethiopia's Grand Renaissance Dam: implications for downstream riparian countries. J Water Resour Plan Manag 141. https://doi.org/10.1061 /(ASCE)WR.1943-5452.0000520

Zou J, Zhan C, Zhao R et al (2018) Impacts of water consumption in the Haihe Plain on the climate of the Taihang Mountains. North China Adv Meteorol 2018. https://doi.org/10.1155/2018/6280737

Publisher's note Springer Nature remains neutral with regard to jurisdictional claims in published maps and institutional affiliations. 